\title{
PENERAPAN SAK ETAP TERHADAP LAPORAN ARUS KAS PADA PT. RIUNG MITRA LESTARI EMBALUT
}

\author{
Lewi Malisan, Devi Putri Milanda ${ }^{1}$ \\ Iwin Trisma Suganda ${ }^{2}$ \\ Dosen Fakultas Ekonomi Jurusan Akuntansi UWGM Samarinda ${ }^{1}$ \\ Mahasiswa Fakultas Ekonomi Jurusan Akuntansi UWGM Samarinda ${ }^{2}$ \\ fekonuwgm@gmail.ac.id
}

\begin{abstract}
ABSTRAK
Tujuan dan manfaat dari penelitian ini adalah mengetahui kesesuaian laporan arus kas pada PT Riung Mitra Lestari dengan Standar Akuntansi Keuangan Entitas Tanpa Akuntabilitas Publik (SAK ETAP). Adapun manfaat yang dapat dirasakan bagi peneliti dapat lebih memahami mengenai laporan arus kas dan bagi perusahaan sebagai masukan pertimbangan pengambilan kebijakan lebih lanjut terhadap laporan arus kas.

Akuntansi keuangan merupakan bidang akuntansi yang berkaitan degan bagaimana pencatatan dan penyusunan laporan keuangan dari satu kesatuan unit usaha yang berpedoma pada prinsip-prinsip yang berlaku.

Metode yang digunakan penulis meneliti permasalahan yaitu metode komparatif antara yang terjadi sesungguhnya di lapangan PT Riung Mitra Lestari dengan Standar yang ada di dalam SAK ETAP terhadap laporan arus kas.
\end{abstract}

Kata Kunci : SAK ETAP, Laporan Arus Kas

\section{ABSTRACT}

The purpose and benefit of this study is to determine the suitability of cash flow reports at PT Riung Mitra Lestari with Entity Financial Accounting Standards Without Public Accountability (SAK ETAP). The benefits that can be felt for researchers can better understand the cash flow statement and for the company as input for consideration of further policy making on the cash flow statement. Financial accounting is an accounting field related to how the recording and preparation of financial statements from a single unit of business based on applicable principles.

The method used by the writer examines the problem, namely the comparative method between what actually happens in the PT Riung Sustainable Partners field and the Standards contained in SAK ETAP on the cash flow statement.

Keywords : SAK ETAP, Cash Flow Statement 
JURNAL EKONOMIKA

https://journal.uwgm.ac.id/index.php/ekonomika/index

2580-8117 E-ISSN, 2527-6379 P-ISSN

Desember 2017, VOL.2 No.2

\section{Pendahuluan}

Latar Belakang

Dalam kaitannya dengan komponen laporan keuangan yang lain, laporan arus kas dapat memberikan informasi bagi pelaku ekonomi untuk mengevaluasi perubahan dalam aktiva bersih perusahaan, dan struktur keuangan. Laporan arus kas dapat memberikan gambaran bagi pelaku ekonomi untuk memahami hubungan antara laba bersih yang disajikan dalam laporan laba rugi dengan arus kas bersih perusahaan yang digunakan atau diterima dari aktivitas operasi dan kebijakan pimpinan perusahaan dalam pengalokasian kas pada kegiatan investasi dan pendanaan. Laporan arus kas menyediakan informasi atas dasar kas mengenai aktivitas operasi, investasi dan pendanaan yang berguna bagi para pemakai laporan keuangan dalam pengambilan keputusan. Dalam proses pengambilan keputusan ekonomi, para pemakai laporan keuangan perlu melakukan evaluasi terhadap kemampuan perusahaan dalam menghasilkan kas serta kepastian perolehannya.

Informasi laba dalam laporan laba rugi dihasilkan atas dasar akuntansi akrual dimana penghasilan dan beban diakui pada saat kejadian, bukan pada saat kas atau setara kas diterima sehingga angka laba yang ditunjukkan bukan merupakan konsekuensi kas yang sifatnya langsung. Sedangkan informasi arus kas disusun atas dasar kas dan setara kas. Informasi laba yang ditunjukkan dalam laporan laba rugi dan informasi arus kas mencerminkan aspek-aspek yang berbeda dari transaksi-transaksi atau peristiwa yang lain yang sama. Sehingga kedua laporan ini menyediakan gambaran yang lengkap bagi pelaku ekonomi tentang kinerja dan perubahan posisi keuangan perusahaan. Untuk itu dapat dimengerti bahwa laporan arus kas merupakan salah satu bagian penting dari laporan keuangan bagi pemakainya.

Setiap perusahaan harus menyajikan laporan arus kas dengan tepat sesuai Prinsip Akuntansi Yang Berlaku Umum. Di Indonesia ada empat pilar Standar Akuntansi Yang Berlaku, yaitu Standar Akuntansi Keuangan (SAK), Standar Akuntansi Keuangan Entitas Tanpa Akuntabilitas Publik (SAK ETAP), Standar Akuntansi Syari'ah dan Standar Akuntansi Pemerintahan. Standar Akuntansi keuangan (SAK) ditunjukkan bagi entitas yang mempunyai tanggung jawab publik signifikan dan entitas yang banyak melakukan kegiatan lintas Negara seperti : perusahaan publik, perbankan dan asuransi. Sedangkan Standar Akuntansi Keuangan Entitas Tanpa Akuntabilitas Publik (SAK ETAP) ini dimaksudkan untuk digunakan oleh entitas tanpa akuntabilitas publik. Entitas tanpa akuntabilitas publik yang dimaksud adalah entitas yang tidak memiliki akuntabilitas publik signifikan dan menerbitkan laporan keuangan untuk tujuan umum bagi pengguna internal.Contoh pengguna internal adalah pemilik, manajemen, pegawai perusahaan dan komisaris. Standar Akuntansi Keuangan Entitas Tanpa 
JURNAL EKONOMIKA

https://journal.uwgm.ac.id/index.php/ekonomika/index

2580-8117 E-ISSN, 2527-6379 P-ISSN

Desember 2017, VOL.2 No.2

Akuntabilitas Publik (SAK ETAP) merupakan Standar Akuntansi Keuangan versi mudah yang ditujukan khusus untuk perusahaan kecil dan menengah.

Adapun perusahaan yang menjadi objek penelitian adalah PT Riung Mitra Lestari di Embalut, suatu perusahaan yang bergerak di bidang jasa kontraktor, tranding pertambangan. Perusahaan telah memiliki laporan keuangan arus kas dalam komponen laporan keuangannya. Penyajiannya yang terdiri dari kas masuk dan kas keluar. Sementara, apabila laporan arus kas disusun dan disajikan sesuai dengan standar yang berlaku yaitu Standar Akuntansi Keuangan Entitas Tanpa Akuntabilitas Publik (SAK ETAP) Terhadap Laporan Arus Kas terdapat pengklasifikasian transaksi atau peristiwa akuntansi ke dalam klasifikasi arus kas yaitu aktivitas operasi, investasi dan pendanaan. Pengklasifikasian arus kas ini penting dilakukan untuk mengevaluasi arus kas yang terjadi dan memprediksi arus kas masa depan. Sehingga para pemakai laporan bisa mendapatkan informasi yang lebih jelas tentang perkembangan perusahaan dan membedakan antara kegiatan berulang yang terus berlangsung dan perubahan strategi jangka panjang.

\section{Permasalahan}

Berdasarkan latar belakang permasalahan yang telah dikemukakan sebelumnya, maka akan menjadi pembahasan utama dan merupakan permasalahan ini adalah "Apakah penyajian arus kas pada PT Riung Mitra Lestari sudah sesuai dengan Standar Akuntansi Keuangan Entitas Tanpa Akuntabilitas Publik (SAK ETAP) Terhadap laporan arus kas

\section{Penelitian Terdahulu}

Penelitian ini dilakukan tidak terlepas dari hasil penelitian-penelitian terdahulu yang pernah dilakukan sebagai bahan perbandingan dan kajian. Penjelasan penelitian terdahulu dapat dilihat secara ringkas sebagai berikut :

Tabel 1. Daftar Penelitian Terdahulu

\begin{tabular}{|c|c|c|c|}
\hline Keterangan & \multicolumn{3}{|c|}{ Penelitian Terdahulu } \\
\hline $\begin{array}{l}\text { Nama } \\
\text { Peneliti }\end{array}$ & Nani Ruswanti Tarno & Juliana Ligit & Iwin Trisma Suganda \\
\hline $\begin{array}{l}\text { Judul } \\
\text { Penelitian }\end{array}$ & $\begin{array}{lrr}\text { "Penerapan } & \text { Standar } & \text { Akuntansi } \\
\text { Keuangan } & \text { Entitas } & \text { Tanpa } \\
\text { Akuntabilitas Publik Bab } 7 \text { Tentang } \\
\text { Laporan Arus Kas Pada PT Rio } \\
\text { Utama Di Samarinda Seberang" }\end{array}$ & $\begin{array}{l}\text { "Analisis Laporan Arus Kas Sesuai } \\
\text { dengan Standar Akuntansi Keuangan } \\
\text { Entitas Tanpa Akuntabilitas Publik } \\
\text { Bab } 7 \text { Pada PT Danny Samudera Raya } \\
\text { Line" }\end{array}$ & $\begin{array}{l}\text { "Penerapan SAK ETAP } \\
\text { Terhadap Laporan Arus } \\
\text { Kas Pada PT Riung } \\
\text { Mitra Lestari" }\end{array}$ \\
\hline Tahun & 2014 & 2012 & 2017 \\
\hline Variabel & Variabel Kualitatif & Variabel Kualitatif & Variabel Kualitatif \\
\hline
\end{tabular}


JURNAL EKONOMIKA

https://journal.uwgm.ac.id/index.php/ekonomika/index

2580-8117 E-ISSN, 2527-6379 P-ISSN

Desember 2017, VOL.2 No.2

\begin{tabular}{|c|c|c|c|}
\hline Universitas & Universitas mulawarman Samarinda & Universitas Politeknik Samarinda & $\begin{array}{c}\text { Universitas } \\
\text { Widyagama Mahakam } \\
\text { Samarinda }\end{array}$ \\
\hline $\begin{array}{l}\text { Metode } \\
\text { Analisis }\end{array}$ & Komparatif & Komparatif & Komparatif \\
\hline $\begin{array}{l}\text { Alat } \\
\text { Analisis }\end{array}$ & Metode Tidak Langsung & Metode Tidak Langsung & Metode Tidak Langsung \\
\hline $\begin{array}{l}\text { Hasil } \\
\text { Penelitian }\end{array}$ & $\begin{array}{l}\text { Hasil penelitian menunjukkan bahwa } \\
\text { perusahaan belum menerapkan Standar } \\
\text { Akuntansi Keuangan Tanpa Akuntabilitas } \\
\text { Publik (SAK ETAP) Bab } 7 \text { dalam } \\
\text { penyusunan laporan arus kas, dimana } \\
\text { perusahaan belum mengelompokkan } \\
\text { aktivitas perusahaan atas aktivitas operasi, } \\
\text { investasi dan pendanaan. Secara } \\
\text { keseluruhan analisis dan evaluasi terhadap } \\
\text { laporan arus kas masuk dan arus kas keluar } \\
\text { tidak dapat melengkapi informasi yang } \\
\text { diberikan laporan keuangan lainnya dalam } \\
\text { mengevaluasi perubahan aktiva bersih } \\
\text { perusahaan, struktur keuangan dan } \\
\text { kemampuan untuk mempengaruhi jumlah } \\
\text { arus kas yang pada akhirnya tidak dapat } \\
\text { dijadikan sebagai dasar kebijakan } \\
\text { pengambilan keputusan manajemen untuk } \\
\text { pencapaian tujuan perusahaan.laporan arus } \\
\text { kas PT Rio Utama untuk tahun yang } \\
\text { berakhir 31 Desember 2011 belum } \\
\text { menggunakan SAK ETAP Bab } 7 \text { sehingga } \\
\text { tidak menghasilkan nilai balance }\end{array}$ & $\begin{array}{l}\text { Berdasarkan hasil penelitian diketahui } \\
\text { bahwa PT Danny Samudera Raya Line } \\
\text { dalam menjalankan kegiatan akuntansinya } \\
\text { lebih khusus lagi pada pencatatan laporan } \\
\text { arus kas dengan metode tidak langsung } \\
\text { tidak sepenuhnya sesuai dengan SAK } \\
\text { ETAP. Ketidaksesuai tersebut dapat } \\
\text { diketahui pada perhitungan bahwa PT } \\
\text { Danny Samudera Raya Line pada aktivitas } \\
\text { operasi yang terdiri dari pos akun naik } \\
\text { turunnya saldo piutang, naik turunnya saldo } \\
\text { utang serta turunya saldo uang muka. Pada } \\
\text { aktivitas investasi hanya terdiri dari } \\
\text { kegiatan investasi. Pada aktrivitas } \\
\text { pendanaan dikarenakan turunnya saldo } \\
\text { utang BPD yang dilakukan PT Danny } \\
\text { Samudera Raya Line dalamkredit investasi. } \\
\text { Sedangkan menurut SAK ETAP pada } \\
\text { aktivitas operasi dengan akun tertentu saja } \\
\text { tidak keseluruhan pos akun dimasukkan. } \\
\text { Hal ini dikarenakan pengklasifikasian telah } \\
\text { dicatat pada aktivitas pendanaan. }\end{array}$ & $\begin{array}{l}\text { Berdasarkan } \\
\text { penelitian yang dilakukan } \\
\text { bahwa PT Riung Mitra } \\
\text { Lestari telah membuat } \\
\text { laporan keuangan tetapi } \\
\text { dalam penyusunan tersebut } \\
\text { belum sesuai denga } \\
\text { ketentuan pembuatan arus } \\
\text { kas yang teleh } \\
\text { distandarisasikan di dalam } \\
\text { SAK ETAP terhadap } \\
\text { laporan arus kas. Secara } \\
\text { keseluruhan analisis dan } \\
\text { evaluasi Pt Riung Mitra } \\
\text { Lestari dari aktivitas arus } \\
\text { kas masuk dan arus kas } \\
\text { keluar tidak dapat } \\
\text { melengkapi informasi yang } \\
\text { diberikan laporan } \\
\text { keuangan lainnya dalam } \\
\text { mengevaluasi perubahan } \\
\text { aktiva bersih perusahaan, } \\
\text { struktur keuangan dan } \\
\text { kemampuan } \\
\text { mempengaruhi jumlah arus } \\
\text { kas yang pada akhirnya } \\
\text { tidak dapat dijadikan } \\
\text { sebagai dasar kebijakan } \\
\text { pengambilan keputusan } \\
\text { manajemen } \\
\text { pencapaian untuk } \\
\text { perusahaan. tujuan }\end{array}$ \\
\hline
\end{tabular}

Sumber : referensi penelitian terdahulu

\section{Sumber Data Penyusunan Arus Kas Metode Langsung dan Tidak Langsung}

Laporan keuangan arus kas (cash flow statement), laporan yang disusun atau dibuat setelah pembuatan neraca. Laporan ini disusun berdasarkan pada dua sumber data, yaitu data laporan laba rugi periode berjalan (current book) dan neraca periode berjalan dengan neraca periode sebelumnya.

Menurut kieso, et al. (2007) cara penyajian atau bentuknya, laporan keuangan arus kas dibedakan menjadi dua yaitu penyajian langsung (direct method) dan penyajian tidak langsung (indirect method). Secara elemen, tidak ada yang berbeda antara dua cara penyajian laporan keuangan arus kas tersebut, perbedaannya hanya terletak pada penyajian arus kas yang berasal dari kegiatan operasi. 
JURNAL EKONOMIKA

https://journal.uwgm.ac.id/index.php/ekonomika/index

2580-8117 E-ISSN, 2527-6379 P-ISSN

Desember 2017, VOL.2 No.2

1) Metode Langsung

Jika pada penyajian langsung (direct method), arus kas yang berasal dari kegiatan operasional diperinci menjadi dua arus kas yaitu arus kas masuk dan arus kas keluar dan kemudian diperinci lagi dalam beberapa jenis penerimaan atau pengeluaran kas

$\begin{gathered}\begin{array}{c}\text { Cash receipts } \\ \text { from } \\ \text { customers }\end{array}\end{gathered}=\begin{aligned} & \text { Revenues } \\ & \text { from sales }\end{aligned} \quad\left\{\begin{array}{c}+ \text { Decrease in accounts receivable } \\ \text { or } \\ - \text { Increase in accounts receivable }\end{array}\right.$

$\begin{gathered}\text { Cash payments } \\ \text { for operating } \\ \text { expenses }\end{gathered}$
Opperating
expenses $\quad\left\{\begin{array}{c}+ \text { Increase in } \\ \text { prepaid expense } \\ \text { or } \\ -\begin{array}{l}\text { Decrease in } \\ \text { prepaid expense }\end{array}\end{array}\left\{\begin{array}{c}+ \text { Decrease in accrued } \\ \text { expenses payable } \\ \text { or } \\ - \text { Increase in accrued } \\ \text { expenses payable }\end{array}\right.\right.$

2) Metode Tidak Langsung

Penyajian tidak langsung (indirect method), arus kas dari kegiatan operasional ditentukan dengan mengoreksi laba bersih yang dilaporkan pada laporan laba rugi (biaya penyusutan, kenaikan harta lancar dan hutang lancar serta laba/ rugi).

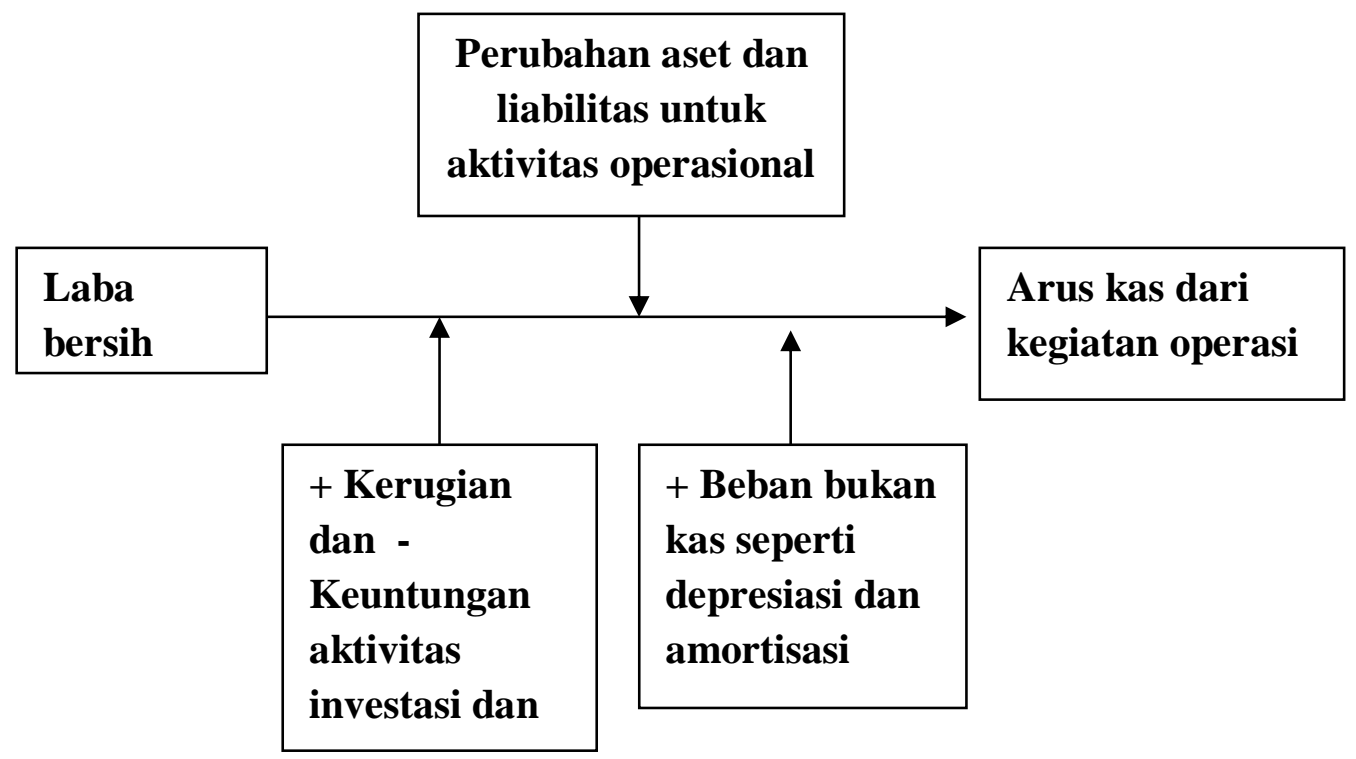


JURNAL EKONOMIKA

https://journal.uwgm.ac.id/index.php/ekonomika/index

2580-8117 E-ISSN, 2527-6379 P-ISSN

Desember 2017, VOL.2 No.2

\section{Kerangka Pikir}

Dalam pembahasan ini akan disampaikan kerangka pikir tioritis yang menggambarkan suatu kerangka konseptual yang merupakan panduan dari segala perumusan hipotesis dalam bentuk gambar sebagai berikut :

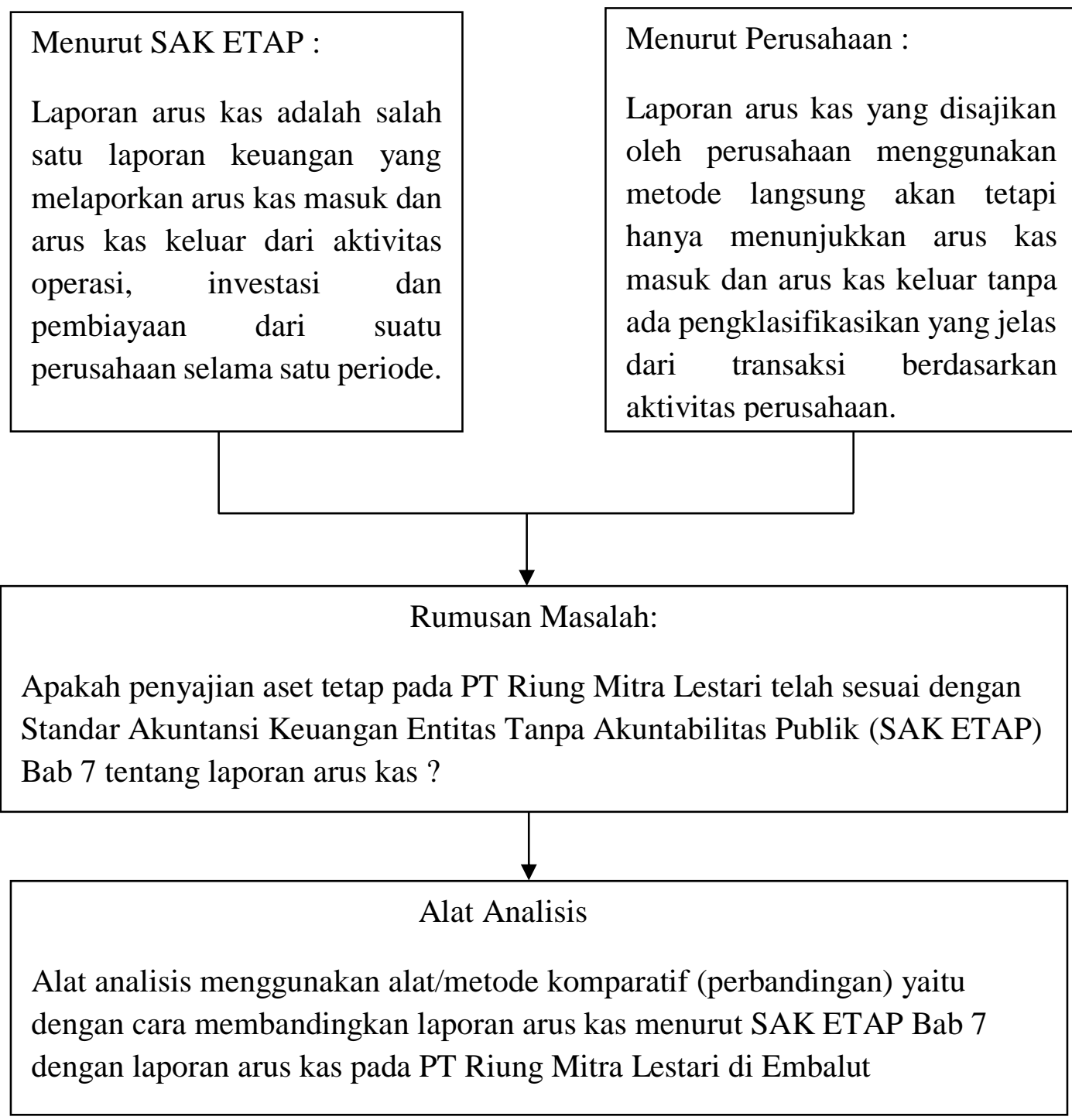

\section{Definisi Operasional Variabel}

Definisi operasional merupakan definisi yang menguraikan variabelvariabel yang akan dianalisis atau dibahas. Untuk memperoleh gambaran yang lebih jelas tentang konsep yang dikemukakan terlebih dahulu, maka perlu kiranya dibuat suatu rumusan atau batasan untuk menerangkan konsep yang dipergunakan, yaitu :

1) PT Riung Mitra Lestari di Embalut merupakan suatu perusahaan yang bergerak dibidang jasa kontraktor, trading dan pertambangan. Dan perusahaan tersebut telah memiliki laporan arus kas dalam komponen laporan keuangannya yang digunakan untuk pengambilan keputusan manajemen. 
JURNAL EKONOMIKA

https://journal.uwgm.ac.id/index.php/ekonomika/index

2580-8117 E-ISSN, 2527-6379 P-ISSN

Desember 2017, VOL.2 No.2

2) Laporan arus kas adalah laporan yang tersusun secara terperinci mengenai bagaimana aktiva, pasiva dan ekuitas pemilik berubah akibat perubahan kas yang diterima perusahaan dan yang dikeluarkan perusahaan yang berasal dari aktivitas, yaitu : Aktivitas operasional pada PT Riung Mitra Lestari adalah penerimaan kas dan pengeluaran kas seperti pembayaran beban, beban dibayar dimuka, pembayaran aset tetap dan Eksplorasi dan evaluasi. Tidak adanya aktivitas investasi pada PT Riung Mitra Lestari. Sedangkan dalam aktivitas pendanaan pada PT Riung Mitra Lestari tidak ada aktivitas.

3) Standar Akuntansi Keuangan Entitas Tanpa Akuntabilitas Publik (SAK ETAP) Bab 7 adalah pedoman yang harus digunakan dalam penyusunan laporan arus kas.

\section{Analisis Data}

Tabel 2. Neraca Komparatif PT. Riung Mitra Lestasi Per 31 Desember 2014 \& 2015

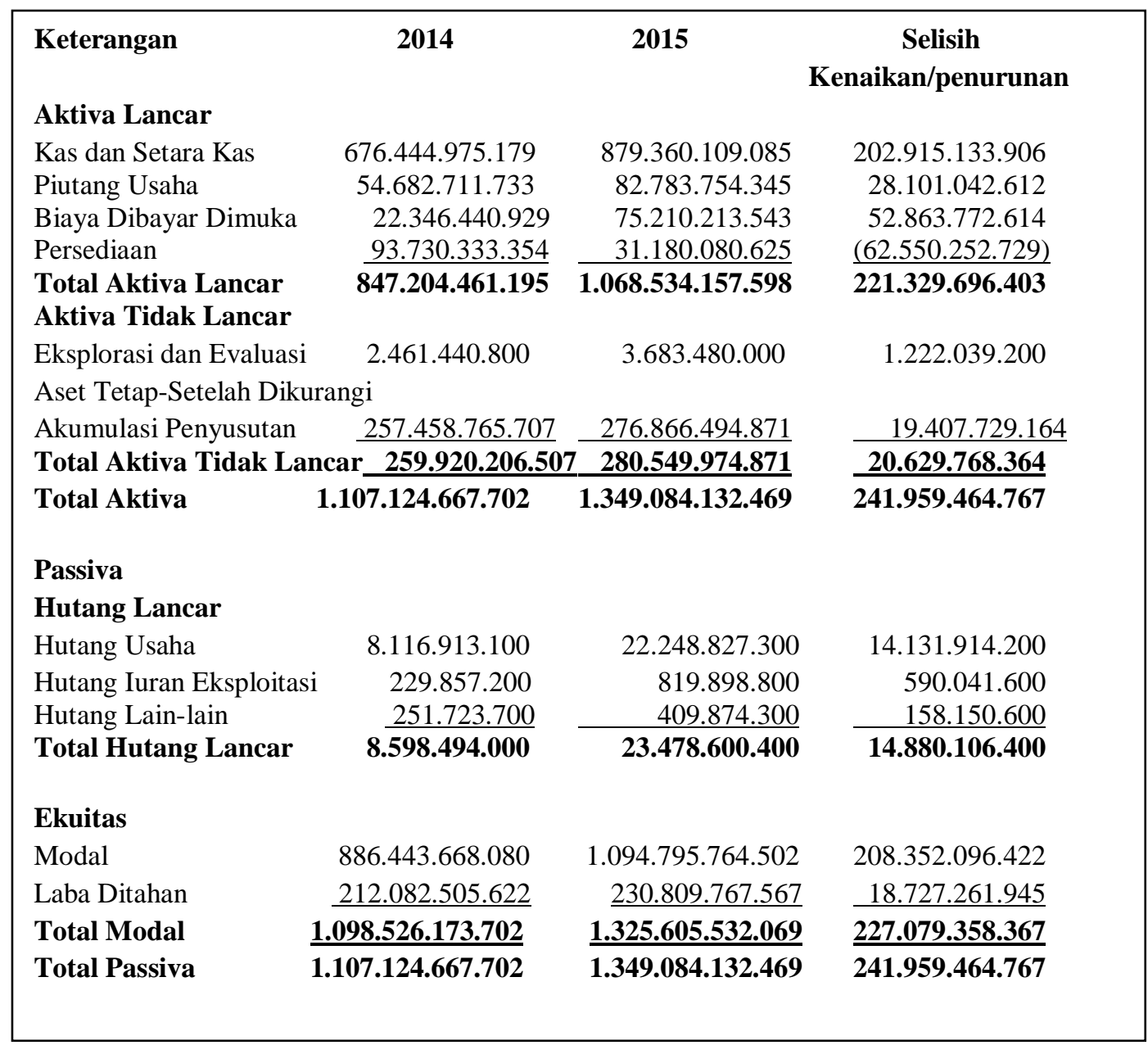


JURNAL EKONOMIKA

https://journal.uwgm.ac.id/index.php/ekonomika/index

2580-8117 E-ISSN, 2527-6379 P-ISSN

Desember 2017, VOL.2 No.2

Tabel 3. Laporan Arus Kas Metode Tidak Langsung Berdasarkan SAK ETAP Bab

PT Riung Mitra Lestari

Laporan Arus Kas

Untuk Periode Yang Berakhir 31 Desember 2015

(Dalam Rupiah)

Laba Bersih

230.809 .767 .567

Penyesuaian untuk merekonsialiasi laba

Arus Kas Bersih Yang Disediakan

Oleh Aktivitas Operasi :

Biaya Depresiasi

10.799.321.394

Kenaikan Piutang Usaha

(28.101.042.612)

Kenaikan Biaya Dibayar Di Muka

$(52.863 .772 .614)$

Penurunan Persediaan

62.550 .252 .729

Kenaikan Iuran Eksploitasi

590.041 .600

Kenaikan Hutang Usaha

14.131.914.200

Kenaikan Hutang Lain-lain

158.150 .600

Arus Kas Bersih dari Aktivitas Operasi

Arus Kas dari aktivitas Investasi

Kenaikan Eksplorasi dan Evaluasi

Kenaikan Aset Tetap

Arus Kas Bersih dari aktivitas Investasi

(20.629.768.364)

Arus Kas Dari Aktivitas Pendanaan

Kenaikan kas dan setara kas

202.915.133.906

Kas pada awal periode

676.444.975.179

Kas Pada Akhir Periode

879.360.109.085

7 PT Riung Mitra Lestari Periode 31 Desember 2015 
JURNAL EKONOMIKA

https://journal.uwgm.ac.id/index.php/ekonomika/index

2580-8117 E-ISSN, 2527-6379 P-ISSN

Desember 2017, VOL.2 No.2

\section{Pembahasan}

Tabel 4. Perbandingan Laporan Arus Kas Perusahaan dengan SAK ETAP

\begin{tabular}{c|l|l}
\hline \multicolumn{1}{c|}{ Keterangan } & \multicolumn{1}{|c}{ Menurut Perusahaan } & Menurut SAK ETAP \\
\hline Aktivitas Operasi & $\begin{array}{l}\text { Adanya penerimaan kas, } \\
\text { pembayaran beban, biaya di } \\
\text { bayar dimuka, pembayaran } \\
\text { aset tetap dan eksplorasi dan } \\
\text { evaluasi }\end{array}$ & $\begin{array}{l}\text { Adanya biaya depresiasi, } \\
\text { kenaikan piutang usaha, } \\
\text { kenaikan biaya dibayar } \\
\text { dimuka penurunan } \\
\text { persediaan, kenaikan } \\
\text { iuran eksploitasi, } \\
\text { kenaikan hutang usaha, } \\
\text { kenaikan hutang lain-lain }\end{array}$ \\
\hline Aktivitas Investasi & $\begin{array}{l}\text { Tidak adanya aktivitas } \\
\text { investasi }\end{array}$ & $\begin{array}{l}\text { Adanya } \\
\text { eksplorasi dan evaluasi, } \\
\text { kenaikan aset tetap }\end{array}$ \\
\hline Aktivitas Pendanaan & $\begin{array}{l}\text { Tidak adanya aktivitas } \\
\text { pendanaan }\end{array}$ & $\begin{array}{l}\text { Tidak adanya aktivitas } \\
\text { pendanaan }\end{array}$ \\
\hline
\end{tabular}

Dari pembahasan diatas maka penyusunan laporan arus kas sebaiknya mengacu pada laporan arus kas sesuai Standar Akuntansi Keuangan Entitas Tanpa Akuntabilitas Publik (SAK ETAP) Bab 7 Metode tidak langsung, karena perusahaan dapat meihat dan menilai kinerja perusahaan dalam menghasilkan kas dari kegiatan operasi dan investasi.

Kas merupakan unsur yang penting bagi suatu perusahaan dalam menjalankan organisasi perusahaan dan pengembangannya untuk mencapai tujuan yang ditetapkan. Oleh karena itu pengelolaan kas harus direncanakan dan diperhitungkan secara tepat untuk menghindari kekurangan kas pada saat dibutuhkan yang dapat mengganggu kegiatan perusahaan ataupun kelebihan kas yang tidak perlu. Laporan arus kas akan menggambarkan arus kas masuk dan arus kas keluar dari aktivitas operasi, aktivitas investasi dan aktivitas pendanaan perusahaan untuk suatu periode tertentu. Laporan arus kas memberikan jawaban atas berbagai masalah seperti apa yang menyangkut perubahan dalam kas, darimana manajemen mendapatkan sumber dana berupa kas, berapa banyak kas yang diperoleh, sehingga pada akhirnya semua informasi yang disajikan laporan arus kas dapat dijadikan dasar kebijakan dalam pengambilan keputusan manajemen untuk pencapaian tujuan perusahaan. 
JURNAL EKONOMIKA

https://journal.uwgm.ac.id/index.php/ekonomika/index

2580-8117 E-ISSN, 2527-6379 P-ISSN

Desember 2017, VOL.2 No.2

\section{Kesimpulan}

1) PT Riung Mitra Lestari belum menerapkan Standar Akuntansi Keuangan Entitas Tanpa Akuntabilitas Publik (SAK ETAP) terhadap laporan arus kas dalam laporan arus kas, dimana perusahaan belum mengelompokkan aktivitas perusahaan atas aktivitas operasi, investasi dan pendanaan.

2) Secara keseluruhan analisis dan evaluasi PT Riung Mitra Lestari dari aktivitas arus kas masuk dan arus kas keluar tidak dapat melengkapi informasi yang diberikan laporan keuangan lainnya dalam mengevaluasi perubahan aktiva bersih perusahaan, struktur keuangan dan kemampuan untuk mempengaruhi jumlah arus kas yang pada akhirnya tidak dapat dijadikan sebagai dasar kebijakna pengambilan keputusan manajemen untuk pencapaian tujuan perusahaan.

3) Laporan arus kas PT Riung Mitra Lestari untuk tahun yang berakhir 31 Desember belum menggunakan Standar Akuntansi Keuanngan Entitas Tanpa Akuntabilitas Publik (SAK ETAP) Terhadap Laporan Arus Kas dengan menggunakan metode tidak langsung.

\section{Saran}

1) PT Riung Mitra Lestari diharapkan menerapkan Standar Akuntansi Keuangan Entitas Tanpa Akuntabilitas Publik (SAK ETAP) terhadap laporan arus kas dalam laporan arus kas,

2) PT. Riung Mitra Lestari harus mengelompokkan aktivitas perusahaan atas aktivitas operasi, investasi dan pendanaan.

3) PT Riung Mitra Lestari dari aktivitas arus kas masuk dan arus kas keluar, agar dapat melengkapi informasi yang diberikan laporan keuangan lainnya dalam mengevaluasi perubahan aktiva bersih perusahaan, struktur keuangan dan kemampuan untuk mempengaruhi jumlah arus kas yang pada akhirnya tidak dapat dijadikan sebagai dasar kebijakna pengambilan keputusan manajemen untuk pencapaian tujuan perusahaan. 
JURNAL EKONOMIKA

https://journal.uwgm.ac.id/index.php/ekonomika/index

2580-8117 E-ISSN, 2527-6379 P-ISSN

Desember 2017, VOL.2 No.2

\section{Daftar Pustaka}

Basu, Swasta DH. (2004). Azas-Azas Marketing, Edisi Ketiga. Yogyakarta.

, (2005). Manajemen Penjualan, Cetakan ke Duabelas. Penerbit Liberty, Yogyakarta.

Carter, Wiliam. K. Dkk, (2006). Akuntansi Biaya. Edisi Ketigabelas. Buku Satu. Jakarta: Salemba Empat.

Donald E.Kieso. Dkk, (1995). Kieso Weygandt Akuntansi Intermediate, Edisi Ketujuh. Jilid 1. Binarupa Aksara, Jakarta.

Dewi, Shintya Purnama. (2015). Analisis Break Even Point Sebagai Perencanaan Laba Pada UD.Bangun Jaya Cabang Samarinda Skripsi (S1), Akuntansi, Fakultas Ekonomi, UWGM, Samarinda.

Halim, Abdul. Dkk, (2009). Akuntansi Manajemen. Edisi Pertama.Yogyakarta: BPFE.

Hansen, Don. R. Dkk, (2006). Akuntansi Biaya. Edisi Ketujuh. Jilid 2. Jakarta: Salemba Empat.

Horngren, (2008), Akuntansi Biaya: Penekanan Manajerial, Jilid 1, PT. INDEKS, Jakarta, Halaman 52.

Jusup, AI. Haryono, (2005). Dasar-Dasar Akuntansi, Edisi Keenam. Jilid 1. Yogyakarta, Penerbit STIE YKPN.

Kuswandi. (2006), Memahami Rasio-Rasio Keuangan, Penerbit PT. Elex Media Komputido, Jakarta

Kasmir. (2010). Pengantar Manajemen Keuangan, Jakarta. Penerbit Kencana Predana Media Grup.

Mulyadi. (2007). Akuntansi Biaya. Edisi Kelima. Yogyakarta: UPP STIM YKPN.

Matz, Adolph dkk. (1992). Akuntansi Biaya Perencanaan dan Pengendalian. Edisi Kesembilan. Jilid 2. Jakarta: Erlangga. 
JURNAL EKONOMIKA

https://journal.uwgm.ac.id/index.php/ekonomika/index

2580-8117 E-ISSN, 2527-6379 P-ISSN

Desember 2017, VOL.2 No.2

Moekijat. (2000). Kamus Manajemen”, Bandung, Penerbit CV. Mandar Maju.

Munawir, H.S. (1995). Analisa Laporan Keuangan, Edisi Keempat penerbit : Liberty Yogyakarta. Halaman 183

Nanu Hasanuh. (2011). Akuntansi Dasar : Teori dan Praktek Jilid 1. Jakarta, Penerbit Mitra Wacana Media.

Ray, Garrison. H. Dkk, (2006). Akuntansi Manajerial. Edisi Ke sebelas. Buku Satu. Jakarta: Salemba Empat.

Rayburn, L. Gayle. (1999). Akuntansi Biaya. Edisi Keenam. Jilid 2. Jakarta:Erlangga.

Syamsuddin, Lukman. (2011). Manajemen Keuangan Perusahaan, Edisi Baru. Jakarta : PT. Raja Grafindo Persada.

Supriyono, R.A. (2000). Akuntansi Biaya, Buku 1. Edisi Kedua. Yogyakarta: BPFE

Slamet Sugiri Sodikin. (2015). Akuntansi Manajemen, Edisi Kelima.UPP, STIM YKPN.

,(2004). Akuntansi Manajemen, Edisi Ketiga, Penerbit YKPN Yogyakarta, Halaman 72

Sigit, Soehardi. (1955), Analisa Break Even Point, Edisi Ketiga, BPFE, Yogyakarta, Halaman 2. 